\title{
Unusual incomplete frontal plane third metacarpal fracture in a dressage horse
}

\author{
Christoph T. Paschke and Ullrich Walliser \\ Pferdeklinik in Kirchheim, Kirchheim unter Teck, Germany
}

\begin{abstract}
Summary: Different types and locations of fractures of the third metacarpal bone have been discussed for decades, especially in regard to treatment and prognosis. There is lack of documentation of frontal plane third metacarpal fractures diagnosed by MRI within the extensive previous literature. The present case report describes an incomplete frontal plane third metacarpal fracture in a dressage horse. The A 6 year-old Hanoverian mare was suddenly lame during side passes within a dressage contest. Physical examination revealed a grade $3 / 5$ lameness of the left forelimb. When standing the horse showed a tendency to leg rest. A discrete oedematous swelling from the medioproximal metacarpus to the middle third of the flexor tendons was palpable. Rotation of the phalanx resulted in a mild pain response. Initially a basic set of x-ray images was carried out, which did not show an evident fractureline. To further evaluate the cause of local swelling and lameness a standing MRI examination was carried out with a 0.27 Tesla Hallmarq EQ2 dedicated equine MRI system. In consequence, an incomplete frontal plane fracture of the third metacarpal bone was confirmed. The images depict typical features of acute fractures in MR studies. Angle adapted x-ray images were taken and the fracture line initially obscured by the splint bones became visible. No diagnostic block was performed due to the risk to worsen the incomplete fracture. Conservative management was chosen. During the first four weeks immobilisation was applied and exercise was restricted to box rest for another four weeks. During that time the mare was re-evaluated regarding to lameness in the walk, by MRI and by $x$-ray images. In the present case conservative management led to complete recovery. The last recheck in the stable took place after 46 weeks by the referring veterinarian. Until that time no signs of secondary osteoarthritis had occurred in follow-up radiographs taken by the referring veterinarian.
\end{abstract}

Keywords: equine, metacarpus, frontal, fracture, cannon bone, mri

Citation: Paschke C. T., Walliser U. (2016) Unusual incomplete frontal plane third metacarpal fracture in a dressage horse. Pferdeheilkunde $32,316-322$

Correspondence: Dr. Christoph T. Paschke, Tierklinik Kirchheim, Nürtingerstraße 200, Kirchheim u. Teck, Germany; E-Mail: cpaschke@gmx.de

\section{Introduction}

Metacarpal fractures occur in all parts of the cannon bone from proximal to distal. Short intracortical stress fractures of the dorsal cortices of Metacarpus III known as 'saucer fractures can be found in different breeds used for disciplines of racing. The predisposed site of occurrence is the dorsal or dorsolateral diaphysis (Cervantes et al. 1992, Hanie et al. 1992, Dallap et al. 1999, Jalim et al. 2010). Cases in which fracture lines spread out from their distal or dorsal original position are well documented (Spurlock 1988, Barr et al. 1989).

Beside these cortical changes, the diaphysis almost exclusively gets involved in comminuted, short transverse or sometimes short oblique fractures of traumatic origin. Sometimes spiral fractures can be diagnosed. Furthermore, greenstick fractures do occur (McClure et al. 1998, Bischofberger et al. 2009). Condylar fractures (Riggs 2002), distal palmar cortical stress fractures (O'Sullivan and Lumsden 2002) and the incomplete proximal fractures (dorsal and palmar) (Lloyd et al. 1988), are supposed to result from a different pathophysiologic mechanism and to be of stress related nature.

Generally main factors evoking fractures of the long bones involve high bending loads and/or rotational forces (Selker and Carter 1989). Furthermore, avulsion fractures at the origin of the suspensory ligament (Bramlage et al. 1980, Booth 2003, Launois et al. 2010) and dorsal cortical fatigue fractures do occur. Additionally, in foals fractures with involvement of the growth plates (Salter-Harris-type) have to be considered (Orsini 2012).
The incidence of cannon bone fractures in regard to all bone fractures is $17.2-17.7 \%$ in racing thoroughbreds (Mizuno 1996). In general, complete fractures of the third metacarpal bone have a prevalence of $22.3 \%$ of all long bone fractures (McClure et al. 1998). Incomplete proximal third metacarpal fractures seem to be comparatively rare (Lloyd et al. 1988, McClure et al. 1998).

Incomplete proximal third metacarpal fractures result in a mild to severe, but predominantly moderate grade of lameness and rather subtle physical findings (Ross et al. 1988, Pleasant et al. 1992). Usually the assumption of a fracture can be made based on radiographic images. If no fracture line is visible trabecular hypertrophy and / or medullary sclerosis in a dorsal to palmar radiographic view and in chronic cases intramedullary sclerosis in a latero-lateral view can hint to fracture. Only in a minority of cases the definite diagnosis of an incomplete proximal third metacarpal bone fracture can be made by radiography only (Lloyd et al. 1988, Ross et al. 1988, Pleasant et al. 1992, Mizuno 1996, O'Sullivan and Lumsden 2002). Oftentimes advanced imaging techniques such as ultrasound (Richardson 2005), nuclear scintigraphy (McClure et al. 1998, O'Sullivan and Lumsden 2002) or magnetic resonance imaging (MRI) are required to secure the fracture diagnosis and to monitor healing.

Furthermore computed tomography (CT) is well established to precisely distinguish structural bony pathology such as (incomplete) fractures and can aid surgical planning (Del Chicca et al. 2008, Braim et al. 2010, O'Brien et al. 2011, Brünisholz et al. 2015). But currently the use of $C T$ is limited as general 
anaesthesia is still prerequisite to the use of this modality in diagnostic imaging of equine limbs (O'Brien et al. 2011).

Undisrupted and healthy subchondral and cortical bone does not give a MRI signal, which results in a black appearance in all MR sequences. Outline and inner margins are well delineated. Due to its structure cancellous bone has an inhomogeneous appearance. On the one hand the bony component lacks any signal and on the other hand the fatty bone marrow component and soft tissues give in general a high signal thus resulting in somewhat grainy and mixed signal intensity. Only in fat suppressed STIR (short $\tau$ inversion recovery) sequences there is no signal resulting from the bone marrow (Martinelli et al. 1996, Tucker and Sande 2001, Breitenseher 2005, Murray and Mair 2005, Murray et al. 2009).

In case of (incomplete) bone fracture the appearance changes markedly. The fissure or fracture line produces a high MR signal and thus becomes visible as a bright white line in most sequences but especially in T2 weighted sequences. Furthermore the surrounding bone matter produces reduced signal intensity in $\mathrm{T} 1$ weighted images or increased signal intensity in STIR as well as in PD (proton density) sequences. It gives a mixed fluid and fat signal which usually shows up very markedly in T2* GRE weighted sequences by its fat / water phase cancellation artefact in active cases (Murray and Mair 2005, Powell 2012, Smith et al. 2012, Ramzan et al. 2015).

Conservative management as well as surgical treatment under general anaesthesia or in a standing procedure are described (Lloyd et al. 1988, Ross et al. 1988, Platt et al. 1990, Pleasant et al. 1992, Payne and Compston 2012). Despite usual involvement of the carpometacarpal joint and the origin of the suspensory ligament simple incomplete fractures of the proximal palmar cortex of the third metacarpal bone are correlated

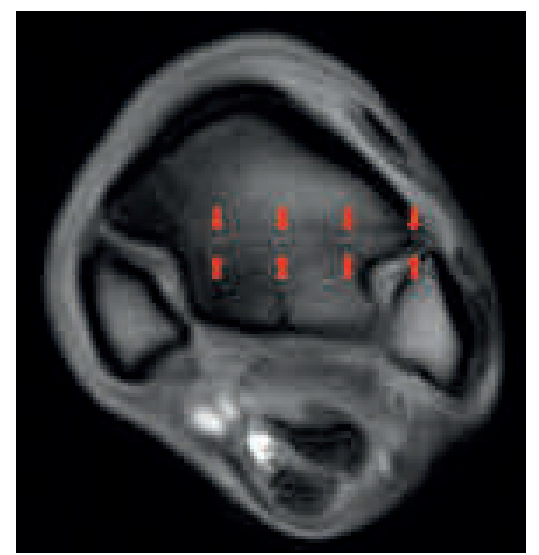

Fig. 1 TIW GRE TRA MI MR image obtained $0.5 \mathrm{~cm}$ distal to the carpometacarpal joint (day 4 after onset of lameness). Lateral is to the right. Discrete linear disruption of the lateral cortical bone plate and the cancellous bone within the cannon bone (between arrows). Adjacend cancellous bone with generalized medium degree of reduced signal especiallally on the medial side. Normally there is mixed signal intensity as present within the unaffected splintbones.

TIW GRE TRA MI MR - Aufnahme gewonnen 0,5 cm distal des Carpometacarpalgelenkes (am 4. Tag nach dem Eintreten der Lahmheitssymptome). Rechts entspricht lateral. Diskrete lineare Unterbrechung der lateralen Corticalis und der spongiösen Knochensubstanz des Röhrbeines (zwischen den Pfeilen). Die umgebende Spongiosa weist eine mittlere, generalisierte Reduktion des Signales besonders der medialen Seite auf. Physiologisch wäre eine gemischte Signalintensität wie diese in den nicht betroffenen Griffelbeinen vorhanden ist. to a good prognosis for soundness even for athletic purposes (Lloyd et al. 1988, Ross et al. 1988, Platt et al. 1990, Pleasant et al. 1992, Payne and Compston 2012).

For this type of fracture a shortened period of convalescence and return to training earlier than three month after injury resulted in a recurrence of lameness (Ross et al. 1988). The mean duration of box rest in horses suffering an incomplete palmar third metacarpal bone fracture is reported to be 6 months and carries a good prognosis with 9 out of 10 horses returning to soundness (Lloyd et al. 1988) with a substantial amount of horses (64\%) returning to full athletic function (Pleasant et al. 1992).

Complications of surgical treatment of third metacarpal fractures can be rather common (19\%) and involve local problems like fragmentation of drill bits, osteomyelitis, disturbed fracture union, catastrophic failure of the cannon bone or local infections as well as more generalised complications like laminitis and colitis (McClure et al. 1998, Lescun et al. 2007). Furthermore, recurrence of the fracture at the same site does occur (Cervantes et al. 1992). To the author's knowledge the present case is the first one in this special location diagnosed by MRI, therefore precedence in therapy and prognosis lacked.

\section{Case History}

A 6 year-old Hanoverian mare was presented to our clinic four days after a sudden onset of non-weight-baring lameness, which occurred during side passes within a dressage

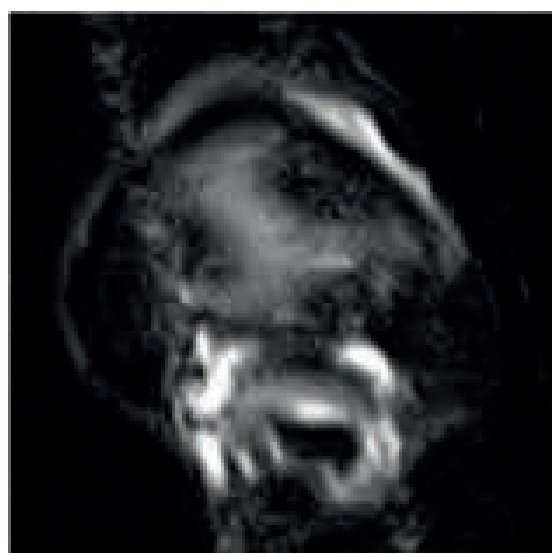

Fig. 2 Short $\tau$ inversion recovery (STIR) FSE TRA MI MR image obtained at the same level and day as image 1. Lateral is to the right. Widespreat increased signal in the cancellous bone adjacend to the fracture site indicating the presence of fluid. Normally there is no fluid signal present as visible within the unaffected splintbones. Note: A similar fluid signal can be seen at the dorsolateral section of the soft tissues at the cannon bone due to their inflammatory response close to the site of compacta / periosteal disruption.

Short $\tau$ inversion recovery (STIR) FSE TRA MI MR - Aufnahme gewonnen auf der gleichen Höhe und am selben Tag wie bei Abbildung 1. Rechts entspricht lateral. Die weitreichende, verstärkte Signalintensität des spongiösen Knochengewebes, das dem Frakturbereich anliegt, weist auf einen erhöhten Flüssigkeitsgehalt hin. Physiologisch wäre ein signalloses Gewebe wie diese in den nicht betroffenen Griffelbeinen sichtbar ist. Beachte: Ein entsprechendes Flüssigkeitssignal tritt im dorsolateralen Abschnitt des Weichteilgewebes auf dem Röhrbein auf. Es ist eine Folge der Entzündungsreaktion an der Unterbrechung von Compacta bzw. Periost. 
contest in which the horse competed according to its age. No history of previous lameness or traumatic incident was known to the owner.

\section{Initial clinical presentation}

When arriving at our facility the mare was grade 3/5 lame in the left front leg independent of the underground on which

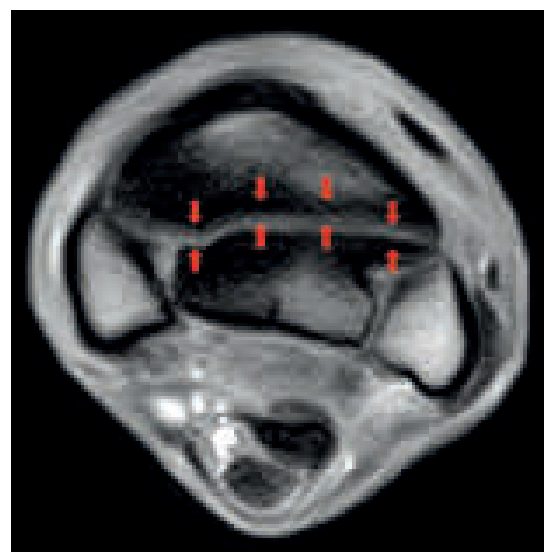

Fig. 3 TIW GRE TRA MI MR image obtained at the same level as image 1 (day 41 after onset of lameness). Lateral is to the right. Marked linear disruption of the lateral cortical bone plate and the cancellous bone whin the cannon bone (between arrows). Adjacend cancellous bone with more focal reduced signal intensity. Normally there is mixed signal as present within the unaffected splintbones. TIW GRE TRA MI MR - Aufnahme gewonnen auf der gleichen Höhe wie bei Abbildung 1 (am 41. Tag nach dem Eintreten der Lahmheitssymptome). Rechts entspricht lateral. Deutliche, lineare Unterbrechung der lateralen Corticalis und der spongiösen Knochensubstanz des Röhrbeines (zwischen den Pfeilen). Die umgebende Spongiosa weist einen örtlich begrenzteren Signalverlust auf. Physiologisch wäre eine gemischte Signalintensität wie diese in den nicht betroffenen Griffelbeinen vorhanden ist.

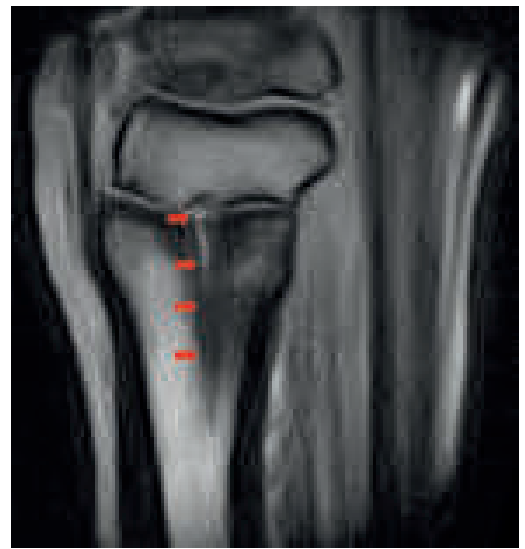

Fig. 4 TIW GRE SAG MI MR image obtained at the same day as image 3. Dorsal is to the left. Marked linear disruption of the subchondral bone plate and the cancellous bone within the proximal cannon bone (arrows). Adjacend cancellous bone with focal reduced signal intensity. Normally there is mixed signal as present within the unaffected third carpal bone.

TIW GRE SAG MI MR - Aufnahme gewonnen am selben Tag wie bei Abbildung 3. Links entspricht dorsal. Deutliche, lineare Unterbrechung der subchondralen Knochenplatte und der spongiösen Knochensubstanz des proximalen Röhrbeines (Pfeile). Die umgebende Spongiosa weist einen örtlich begrenzteren Signalverlust auf. Physiologisch wäre eine gemischte Signalintensität wie diese im nicht betroffenen Os carpale tertium vorhanden ist. the horse was presented. When standing the horse showed a tendency to leg rest. Closer inspection of the limb revealed discrete oedematous swelling from the medioproximal metacarpus to the middle third of the flexor tendons. Digital pulses, hoof testers and filling of the synovial cavities of the distal limb were within normal limits. Rotation of the phalanx resulted in a mild pain response whereas flexion appeared unremarkable.

\section{Diagnostic imaging}

Initially a basic set of $x$-ray images was carried out, which usually consists of a latero-medial $\left(90^{\circ}\right)$, a frontal $\left(0^{\circ}\right)$ and two oblique views $\left(45^{\circ} / 135^{\circ}\right)$ using a FUJIFILM FCR Profect One system. The acquired images did not show evident pathology but an incomplete fracture was assumed.

To further evaluate the cause of local swelling and lameness a standing MRI examination was carried out. A 0.27 Tesla Hallmarq EQ2 dedicated equine MRI system was used and images were acquired in a standard procedure. The sequences used were described by Ramzan and Powell (2010) for the fetlock. Due to increasing discomfort during the examination the study was finished with a shortened protocol. T1 weighted gradient echo (TRA, SAG and FRO), T2* weighted gradient echo (TRA) and short $\tau$ inversion recovery (STIR) fast spin echo (TRA and SAG) were acquired. In consequence, an incomplete frontal plane fracture of the third metacarpal bone was confirmed (Figures 1 and 2). The images depict typical features of an acute (incomplete) fracture in MR studies. Angle adapted $x$-ray images were taken and the fracture line initially obscured by the splint bones became visible (Figure 5). Even tough lameness of incomplete fractures of the proximal third metacarpal bone can improve to a high palmar regional nerve block as described by Lloyd et al. (1988), no diagnostic block was performed due to the risk to worsen the incomplete fracture.

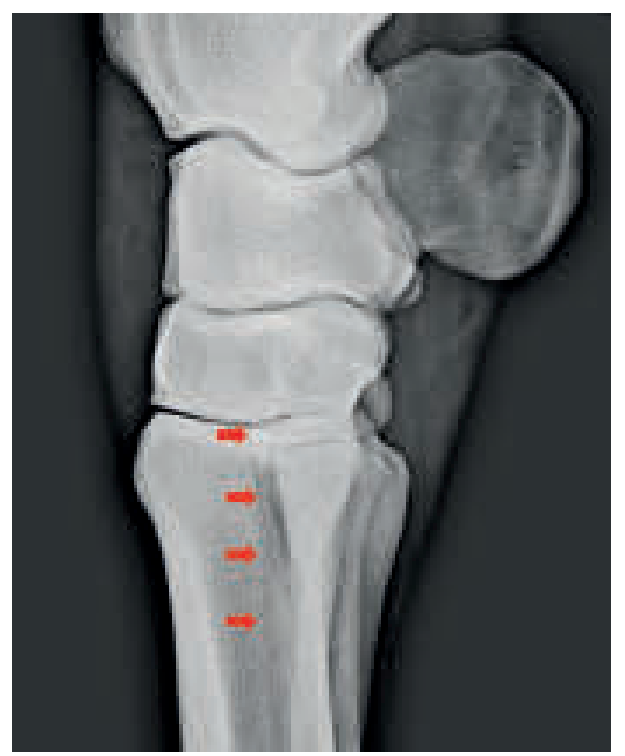

Fig. 5 Angle-adapted latero-lateral radiograph $\left(80^{\circ}\right.$; day 4 after onset of lameness). Fine fissure fracture advancing from the carpomediocarpal joint into the proximal cannon bone.

Winkel-adaptierte Röntgenaufnahme $\left(80^{\circ}\right.$; am 4. Tag nach dem Eintreten der Lahmheitssymptome). Diskrete Fissurlinie, die sich vom Carpometacarpalgelenk in das proximale Röhrbein hinein erstreckt. 


\section{Management}

Surgical treatment / approach was without clear reference for this specific lesion orientation. Given the mare's character and size the risk of recovery from general anaesthesia in absence of a hydropool seamed high. Thus a conservative approach was chosen. During the first four weeks immobilisation with an splint enforced Robert-Jones dressing up to the elbow joint was applied as recommended for first aid by different authors (Smith 1993, Walmsley 1993, Schramme 2005, Aver 2012) until the mare no longer tolerated the bandage. Exercise was restricted to box rest. Due to incompliant behaviour proper cast immobilisation appeared too risky. Whereas splint enforced dressing was tolerated well initially. After treatment a mild focal decubitus was visible. This is a well described complication especially after long term bandaging due to ischemia induced by intense pressure which can result in focal dermal necrosis (Morlock et al. 1997, Payne and Compston 2012). It resolved after removing the bandage without further treatment. During additional four weeks of box rest without bandage the mare was re-evaluated regarding to lameness in the walk, by MRI and by x-ray images. The outline of the bone structure disruption initially became more clearly visible in x-rays after day 14 and was also visible on MR images at day 41 respectively (Figures 3 and 4). This widening of the fracture gap is a typical phase of bone fracture healing, two to three weeks after the formation of a fracture line (Sande 1999). Furthermore, the widespread fluid signal resolves over time, which facilitates a clear delineation of the fracture outline.

During the course of healing a marked callus formation was visible. Eight weeks after admission the horse was released into her owner s care. Over a time of 14 weeks a careful controlled exercise program was installed. Starting with five minutes in hand walking without turns. Later ridden work was invented and the workload subsequently increased. By 26 weeks all passes had been reinvented and the training was extended to the lesson necessary for age appropriate dressage contests.

\section{Outcome/Follow-up}

After 46 weeks the last recheck in the stable took place for routine purposes by the referring veterinarian. By that time the horse had returned to its intended use and was furthermore used for low level jumping exercises without limitations. Until that time no signs of secondary osteoarthritis had occurred in follow-up radiographs taken by the referring veterinarian.

\section{Discussion}

While (incomplete) proximal third metacarpal fractures have been described to occur in a sagittal plain (Lloyd et al. 1988, Ross et al. 1988, Pleasant et al. 1992, Richardson 2005) the recent case demonstrates that (incomplete) frontal plane fracture of the third metacarpal bone can arise and can be treated successfully.

The current case was several years older compared to race horses suffering from different bone stress related fractures which are usually diagnosed in early age of mostly under three years (Cervantes et al. 1992, Dallap et al. 1999, O'Sullivan and Lumsden 2002, Jalim et al. 2010). In general racehorses compete at an early age. In comparison horses used for dressage purposes need to be trained longer for competition, which is reflected in increased age. This age matches other cases of incomplete proximal third metacarpal fractures in non-racehorses in sagittal orientation (Lloyd et al. 1988). Nevertheless, the mare was subsequently undertaking an increasing amount of workload, which might have been inappropriate in regard to the adaptation of her developing bone matter. Typically horses diagnosed with incomplete proximal third metacarpal fractures had a history of altered work type or load (Pleasant et al. 1992).

The proximal third metacarpal bone has an almost oval shape with the cortical bone being thicker in dorsal and palmar components. The areas of contact to the splint bones on either side of the cannon bone have only a thin layer of cortical bone at the very proximal end, resulting in an almost pentagonal shape immediately distal to the carpometacarpal joint (Les et al. 1997, Murray 2007, Sampson and Tucker 2007). The dorsal half of the subchondral bone plate of the cannon bone within carpometacarpal joint is very thick compared to its palmar section (Les et al. 1997, Sampson and Tucker 2007, Nagy and Dyson 2011 ).

During the horses motion the bones are known to physiologically be exposed to three types of force: axial loading / compression, bending and torsion (Selker and Carter 1989). Furthermore, lateral impact due to trauma must be considered which can result in cannon bone fractures (Bischofberger et al. 2009). Ex vivo cannon bone specimens of thoroughbred race horses predominantly suffer longitudinal bone cracks evolving from one of the ends (Cheney et al. 1973). Generally, main factors evoking fatigue fractures of the long bones involve high bending loads and / or rotational forces (Selker and Carter 1989). Due to its oval shape the cannon bone of the horse represents a structure optimised for dorsal bending and thus is naturally less well prepared to cope with sagital bending (Les et al. 1997). The fact of side passes entailing a high degree of dynamic sagital bending in addition to the other forces affecting the long bones during competitions might have contributed to pathogenesis in the present case albeit this kind of lesion seems to be very rare.

Furthermore, in vitro examinations in isolated bone loading models have proven a significant individual variation of biological resistance to fracture resulting from cyclic overload (Danova et al. 2003). It remains unclear whether the incomplete proximal third metacarpal fracture in a frontal plain is an under diagnosed lesion. The supposed underlying pathogenesis of ill fitted workload in regard to structural adaptation of different loaded structures like bones is a long known problem in racing animals but might become a growing problem in riding populations as well. Increasing rideability and more accentuated gates are clearly goals of horse breeding societies, which allow earlier participation in higher-level competitions. Thus time for adaptation of the musculoskeletal system might get shorter. Nevertheless, third metacarpal fissures and fractures have been reported predominantly in racehorses (standardbred trotters and thoroughbreds) (Cervantes et al. 1992, Pleasant et al. 1992, Ross and Martin 1992, Mizuno 1996, Dallap et al. 1999, Zekas et al. 1999, O'Sullivan and 
Lumsden 2002, Parkin et al. 2004, Parkin et al. 2006, Jalim et al. 2010) even if some reports document a wider range of breeds and uses (Lloyd et al. 1988).

The possible fatal outcome demands an early diagnosis. While $x$-ray is still valuable as a first line diagnostic tool and for recheck examinations for example to monitor for callous formation or signs of osteoarthritis it has its limitations. As once more demonstrated in the recent case in anatomically complex areas tomographic techniques are superior to plain radiographs. This special occurrence of proximal third metacarpal fractures carries the risk of being obscured by the splint bones in latero-lateral radiographic views. Furthermore, the high variation of bone thickness might result in the optical illusion of Mach bands in that very area (Daffner 1989, Nielsen 2001, Reeves 2004). Due to increasing awareness of radiation safety issues and comprehensive availability of standing MRI, early MR evaluation should be considered. Nevertheless, standing MRI of the proximal metatarsal area has its challenges in painful horses, resulting in increased levels of patient motion and thus motion related artefacts.

In the present case early fracture diagnosis was possible. Despite her unpleasant temperament, the mare recovered during conservative management and was able to go back to her intended use. This observation fits an overall positive prognosis and results from the fact that intraarticular fractures are supposed to be more forgiving in joints with a low range of motion (Lloyd et al. 1988, Ross et al. 1988, Pleasant et al. 1992). The present case was even favourable compared to sagital incomplete fractures of palmaro-proximal metacarpus due to lack of suspensory ligament involvement at its attachment.

\section{Manufacturer s addresses}

FUJIFILM Europe GmbH, Düsseldorf, Germany Hallmarq Veterinary Imaging, Guilford, Surrey, UK.

\section{References}

Aver J. A. (2012) Principles of Fracture Treatment. In: Aver, J.A., Stick, J.A. (Eds.), Equine Surgery. Elsevier/Saunders, St. Louis, Mo., pp. 1047-1081

Barr A. R., Sridhar B., Denny H. R. (1989) Long incomplete longitudinal fractures of the third metacarpal and metatarsal bone in horses. Vet. Rec. 124, 580-582

Bischofberger A. S., Fürst A., Aver J., Lischer C. (2009) Surgical management of complete diaphyseal third metacarpal and metatarsal bone fractures: clinical outcome in 10 mature horses and 11 foals. Equine Vet. J. 41, 465-473

Booth T. M. (2003) Proximal suspensory ligament desmitis with suspensory ligament avulsion fractures. Equine Vet. Educ. 15, 132-133

Braim A. E. P., Bell R. J. W., Textor J. A., Lo W. Y., Puchalski S. M., Galuppo L. D. (2010) Computed tomography of proximal metatarsal and concurrent third tarsal bone fractures in a Thoroughbred racehorse. Equine Vet. Educ. 22, 290-295

Bramlage L. R., Gabel A. A., Hackett R. P. (1980) Avulsion fractures of the origin of the suspensory ligament of the horse. J. Am. Vet. Med. Assoc. 176, 1004-1010

Breitenseher M. (2005) MR imaging strategies for the lower extremities. Thieme, Stuttgart

Brünisholz H. P., Hagen R., Fürst A. E., Kümmerle J. M. (2015) Radiographic and Computed Tomographic Configuration of Incomplete Proximal Fractures of the Proximal Phalanx in Horses Not Used for Racing. Vet. Surg. 44, 809-815
Cervantes C., Madison J. B., Ackerman N., Reed W. O. (1992) Surgical treatment of dorsal cortical fractures of the third metacarpal bone in thoroughbred racehorses: 53 cases (1985-1989). J. Am. Vet. Med. Assoc. 200, 1997-2000

Cheney J. A., Liou S. Y., Wheat J. D. (1973) Cannon-bone fracture in the thoroughbred racehorse. Med. Biol. Eng. 613-620

Daffner R. H. (1989) Visual illusions in the interpretation of the radiographic image. Curr. Probl. Diagn. Radiol. 18, 62-87

Dallap B. L., Bramlage L. R., Embertson R. M. (1999) Results of screw fixation combined with cortical drilling for treatment of dorsal cortical stress fractures of the third metacarpal bone in 56 Thoroughbred racehorses. Equine Vet. J. 31, 252-257

Danova N. A., Colopy S. A., Radtke C. L., Kalscheur V. L., Markel M. D., Vanderby R., McCabe R. P., Escarcega A. J., Muir P. (2003) Degradation of bone structural properties by accumulation and coalescence of microcracks. Bone 33, 197-205

Del Chicca F., Kümmerle J. M., Ossent P., Nitzl D., Fürst A., Ohlerth S. (2008) Use of computed tomography to evaluate a fracture associated with a subchondral pedal bone cyst in a horse. Equine Vet. Educ. 20, 515-519

Hanie E. A., Sullins K. E., White N. A. (1992) Follow-up of 28 horses with third metacarpal unicortical stress fractures following treatment with osteostixis. Equine Vet. J. Suppl. 5-9

Jalim S. L., Mcilwraith C. W., Goodman N. L., Anderson G. A. (2010) Lag screw fixation of dorsal cortical stress fractures of the third metacarpal bone in 116 racehorses. Equine Vet. J. 42, 586-590

Launois T., Desbrosse F., Perrin R. (2010) Percutaneous osteostixis as treatment for avulsion fractures of the palmar/plantar third metacarpal/metatarsal bone cortex at the origin of the suspensory ligament in 29 cases. Equine Vet. Educ. 15, 126-138

Les C. M., Stover S. M., Keyak J. H., Taylor K. T., Willits N. H. (1997) The distribution of material properties in the third metacarpal bone serves to enhance sagittal bending. J. Biomech. 30, 355-361

Lescun T. B., McClure S. R., Ward M. P., Downs C., Wilson D. A., Adams S. B., Hawkins J. F., Reinertson E. L. (2007) Evaluation of transfixation casting for treatment of third metacarpal, third metatarsal, and phalangeal fractures in horses: 37 cases (1994-2004). J. Am. Vet. Med. Assoc. 230, 1340-1349

Lloyd K. C., Koblik P., Ragle C., Wheat J. D., Lakritz J. (1988) Incomplete palmar fracture of the proximal extremity of the third metacarpal bone in horses: ten cases (1981-1986). J. Am. Vet. Med. Assoc. 192, 798-803

Martinelli M. J., Baker G. J., Clarkson R. B., Eurell J. C., Pijanowski G. J., Kuriashkin I. V., Carragher B. O. (1996) Correlation between anatomic features and low-field magnetic resonance imaging of the equine metacarpophalangeal joint. Am. J. Vet. Res. 57, 1421-1426

McClure S. R., Watkins J. P., Glickman N. W., Hawkins J. F. and Glikkman L. T. (1998) Complete fractures of the third metacarpal or metatarsal bone in horses: 25 cases (1980-1996). J. Am. Vet. Med. Assoc. 213, 847-850

Mizuno Y. (1996) Fractures of the carpus in racing thoroughbreds of the Japan racing association: prevalence, location and current modes of surgical therapy. J. Equine Vet. Sci. 16, 25-31

Morlock M. M., Nassutt R., Bonin V. (1997) The influence of bandage characteristics and inter-individual application variations on underneath bandage pressures. Clin. Biomech. (Bristol, Avon) 12, S 10

Murray R. (2007) Magnetic Resonance Imaging of the Equine Carpus. Clin. Tech. Equine Pract. 6, 86-95

Murray R. C., Mair T. (2005) Use of magnetic resonance imaging in lameness diagnosis in the horse. In Pract. 27, 138-146

Murray R. C., Mair T. S., Sherlock C. E., Blunden A. S. (2009) Comparison of high-field and low-field magnetic resonance images of cadaver limbs of horses. Vet. Rec. 165, 281-288

Nagy A., Dyson S. J. (2011) Magnetic Resonance Anatomy of the Carpus of the Horse Described From Images Acquired From Low-Field and High-Field Magnets. Vet. Radiol. Ultrasound 52, 273-283

Nielsen C. J. (2001) Effect of scenario and experience on interpretation of mach bands. J. Endod. 27, 687-691 
O'Brien T., Baker T. A., Brounts S. H., Sample S. J., Markel M. D., Scollay M. C., Marquis P., Muir P. (2011) Detection of Articular Pathology of the Distal Aspect of the Third Metacarpal Bone in Thoroughbred Racehorses: Comparison of Radiography, Computed Tomography and Magnetic Resonance Imaging. Vet. Surg. 40, 942-951

O'Sullivan C. B., Lumsden J. M. (2002) Case Report Distal third metacarpal bone palmar cortical stress fractures in four Thoroughbred racehorses. Equine Vet. Educ. 14, 70-75

Orsini J. A. (2012) A Fresh Look at the Process of Arriving at a Clinical Prognosis Part 4: Fractures. J. Equine Vet. Sci. 32, 129-138

Parkin T. D. H., Clegg P. D., French N. P., Proudman C. J., Riggs C. M., Singer E. R., Webbon P. M., Morgan K. L. (2004) Risk factors for fatal lateral condylar fracture of the third metacarpus/metatarsus in UK racing. Equine Vet. J. 37, 192-199

Parkin T. D. H., Clegg P. D., French N. P., Proudman C. J., Riggs C. M., Singer E. R., Webbon P. M., Morgan K. L. (2006) Catastrophic fracture of the lateral condyle of the third metacarpus/metatarsus in UK racehorses - Fracture descriptions and pre-existing pathology. Vet. J. 171, 157-165

Payne R. J., Compston P. C. (2012) Short- and long-term results following standing fracture repair in 34 horses. Equine Vet. J. 44, 721-725

Platt I. M. W. D., Houlton J. E. F., College R. V., Mymms N. (1990) Management of intracortical fractures of the palmaroproximal third metacarpal bone in a horse by surgical forage. Equine Vet. J. 22, 142-144

Pleasant R. S., Baker G. J., Muhlbaver M. C., Foreman J. H., Boero M. J. (1992) Stress reactions and stress fractures of the proximal palmar aspect of the third metacarpal bone in horses: 58 cases (1980-1990). J. Am. Vet. Med. Assoc. 201, 1918-1923

Powell S. E. (2012) Low-field standing magnetic resonance imaging findings of the metacarpo/metatarsophalangeal joint of racing Thoroughbreds with lameness localised to the region: a retrospective study of 131 horses. Equine Vet. J. 44, 169-177

Ramzan P. H. L., Palmer L., Powell S. E. (2015) Unicortical condylar fracture of the Thoroughbred fetlock: 45 cases (2006-2013). Equine Vet. J. 47, 680-683

Ramzan P. H. L., Powell S. E. (2010) Clinical and imaging features of suspected prodromal fracture of the proximal phalanx in three Thoroughbred racehorses. Equine Vet. J. 42, 164-169

Reeves P. (2004) Visions of normality? Early experiences of radiographic reporting. Radiography 10, 213-216

Richardson D. W. (2005) Chapter 95: Metacarpal and Metatarsal Bones. , Third Edit. ed, Equine Surgery. Elsevier Inc.

Riggs C. M. (2002) Fractures - A preventable hazard of racing thoroughbreds? Vet. J. 163, 19-29

Ross M. W., Ford T. S., Orsini P. G. (1988) Incomplete Longitudinal Fracture of the Proximal Palmar Cortex of the Third Metacarpal Bone in Horses. Vet. Surg. 17, 82-86

Ross M. W. Martin B. B. (1992) Dorsomedial articular fracture of the proximal aspect of the third metacarpal bone in standardbred racehorses: seven cases (1978-1990). J. Am. Vet. Med. Assoc. 201, 332-335

Sampson S. N., Tucker R. L. (2007) Magnetic Resonance Imaging of the Proximal Metacarpal and Metatarsal Regions. Clin. Tech. Equine Pract. 6, 78-85

Sande R. (1999) Radiography of Orthopedic Trauma and Fracture Repair. Vet. Clin. Small Anim. Pract. 29, 1247-1260

Schramme M. C. (2005) The Robert Jones Bandage. Equine Vet. Educ. 1, 50-51

Selker F., Carter D. R. (1989) Scaling of long bone fracture strength with animal mass. J. Biomech. 22, 1175-1183

Smith M. A., Dyson S. J., Murray R. C. (2012) Reliability of high- and low-field magnetic resonance imaging systems for detection of cartilage and bone lesions in the equine cadaver fetlock. Equine Vet. J. 44, 684-691

Smith R. K. W. (1993) Bandages and casts. Equine Vet. Educ. 5, 108-112

Spurlock G. H. (1988) Propagation of a dorsal cortical fracture of the third metacarpal bone in two horses. J. Am. Vet. Med. Assoc. $192,1587-1589$
Tucker R. L., Sande R. D. (2001) Computed tomography and magnetic resonance imaging of the equine musculoskeletal conditions. Vet. Clin. North Am. Equine Pract. 17, 145-57

Walmsley J. I. (1993) First aid splinting for the equine fracture patient. Equine Vet. Educ. 5, 61-63

Zekas L. J., Bramlage L. R., Embertson R. M., Hance S. R. (1999) Results of treatment of 145 fractures of the third metacarpal/metatarsal condyles in 135 horses (1986-1994). Equine Vet. J. 31, 309-313

Erweiterte Zusammenfassung

\section{Eine ungewöhnliche Röhrbeinfraktur an der Vorder- gliedmaße eines Dressurpferdes}

Eine 6-jährige Hannoveraner Stute zeigte während der Traversale in einem Dressurwettbewerb plötzlich eine hochgradige Lahmheit einer Vordergliedmaße. Es waren weder ein vorangegangenes Trauma noch eine frühere Lahmheit bekannt. Die Befunde der klinischen Untersuchung beim Eintreffen in der Pferdeklinik umfassten eine Lahmheit Grad 3/5 der linken Vordergliedmaße und die Entlastung des Beines im Stand. Weiterhin war eine diskrete, ödematöse Schwellung vom medioproximalen Röhrbein bis zum mittleren Drittel des Beugesehnenpaketes tastbar. Die Rotation der distalen GliedmaBe resultierte in einer Schmerzreaktion. Auf den initial angefertigten Röntgenaufnahmen in Standardprojektionen war ein Fissurspalt zunächst nicht klar darstellbar, sodass eine Kernspintomographie im Stehen durchgeführt wurde. Dazu wurde ein 0,27 Tesla Hallmarq-EQ2-System verwendet, welches zur Untersuchung der Gliedmaßen am stehenden Pferd entwikkelt wurde. Es war so möglich eine eine inkomplette Fraktur des Metacarpus III zu bestätigen, deren Verlauf das proximale Röhrbein in frontaler Ausrichtung durchmaß.

Die Behandlung erfolgte konservativ mittels Ruhigstellung über vier Wochen und im Anschluss weiteren vier Wochen vollständiger Boxenruhe. Während dieses Zeitraumes erfolgten neben den klinischen Verlaufsuntersuchungen, auch eine Kontrolle mittels Magnetresonanztomographie und wiederholten Röntgenaufnahmen. Dabei war zunächst nach dem 14. (Röntgen) bzw. 41. Tag (Magnetresonanzomographie) eine klarer begrenzte Unterbrechung der Knochenstruktur darstellbar. Weiterhin bildete sich das ausgedehnte Flüssigeitssignal im Laufe der Zeit zurück, sodass die Abgrenzbarkeit der Fissurlinie deutlicher wurde. Mit fortschreitendem Heilungsverlauf war eine deutliche Kallusbildung sichtbar. Acht Wochen nach der Einlieferung in die Pferdeklinik wurde das Pferd in Betreuung des Pferdebesitzers entlassen. Mittels eines kontrollieren Bewegungsprogrammes wurde die Stute über 14 Wochen systematisch aufgebaut. In der 26. Woche nach dem Auftreten der Fraktur war die Genesung soweit fortgeschritten, dass die in einer altergemäßen Dressurprüfung erforderlichen Lektionen wieder trainiert werden konnten. Die letzte Nachuntersuchung fand nach 46 Wochen im Stall des Pferdes durch den betreuenden Haustierarzt statt. Zu diesem Zeitpunkt war das Pferd wieder im Training und wurde auch über leichte Sprünge geritten. Weiterhin ließen sich auf den zu dieser Gelegenheit angefertigten Kontrollröntgenaufnahmen keine Anzeichen einer sekundären Arthrose darstellen.

Schlüsselwörter: Pferd, Metacarpus, frontal, Fraktur, Röhrbein, MRT 